\title{
IAMJ
}

INTERNATIONAL

AYURVEDIC

MEDICAL JOURNAL

$\underline{\text { Review Article }}$

ISSN: 2320-5091

Impact Factor: 6.719

\section{UNDERSTANDING ETIOPATHOGENESIS OF SHEETAPITTA - A CRITICAL REVIEW}

\section{Mokkapati Archana}

Assistant Professor, Sri Jayendra Saraswathi Ayurveda College and Hospital, Nazarathpet, Chennai, Tamil Nadu, India

Corresponding Author: archana.mokkapati8@gmail.com

\section{https://doi.org/10.46607/iamj07p5052021}

(Published online: July 2021)

Open Access

(C) International Ayurvedic Medical Journal, India 2021

Article Received: 14/06/2021 - Peer Reviewed: 03/07/2021 - Accepted for Publication: 03/07/2021

\section{Check for updates}

\section{ABSTRACT}

The disease Sheetapitta (NAMC, Disease morbidity code ED 14) was kept forth by Madhavakara in Rigvinischayam. Vinaya Pitaka, a book from Buddhist literature of about 500 BCE mentioned a disease named Chavidoshabadha (literally mean skin disease) or Julpittee ${ }^{1}$ (a disease which causes red coloured wheals and itching on the body). Sheetapitta like manifestations named Udarda, Kotha, Utkotha., were explained in different contexts since the Samhita period. On the contrary with Ushna and Tikshna guna of Pitta, Sheeta guna was used to name the disease, Sheetapitta. Sheetapitta is characterized by Varati dastavat shotha, Kandu, Daha, Thoda, Jwara, Chardi, where all the tridosha involvement is seen. In this regard, there is uncertainty in determining the Nidana, Samprapthi and Samprapthi ghataka of the disease. Hence, here my present study deals with the nomenclature, detailed nidana, Samprapthi and Chikitsa of Sheetapitta.

Keywords: Sheetapitta, Nomenclature, Nidana, Samprapthi, Chikitsa.

\section{INTRODUCTION}

Sheetapitta is composed of two words Sheeta and Pitta. Sheeta ('Shai + Kta') - Referred as Hima rtu and Twacha in various nighantus ${ }^{2}$. Pitta (Tap Santape)
- Defined as that which is responsible for the heat of the body ${ }^{3}$. This disease is explained after or in Kushta roga in almost all classical treatises of Ayurveda, due 
to their similarity in Twak dushti and involvement of tridoshas. Though Sheetapitta and Udarda were mentioned separately, there is a striking similarity between them and clinically difficult to enumerate separately. Anjana nidana explained Udarda as, the appearance of skin patches look like those caused by the sting of wasp along with Itch, Vomiting, Fever and is caused by Sheeta and Pitta ${ }^{4}$. Madhukosa explained that, though the features of Sheetapitta and Udarda are similar to each other, there is a predominance of vata in Sheetapitta while Udarda is dominated by $k a p h a^{5}$.

\section{DISEASE REVIEW -}

Nidana - Sheeta marutha samsparsha (due to the contact with a cold breeze) the vitiated vata and kapha along with pitta, produces the disease externally on twak and internally involving raktadi dhatus ${ }^{6}$. This shows the dosha dushya samurchana of pitta and rakta. Hence nidana (Table No.1) which cause Rakta dushti are taken into prime consideration here.

Poorva rupa - Pipasa, Aruchi, Hrillasa, Deha sada, Gourava, Rakta lochana are the premonitory symptoms ${ }^{7}$.

Rupa - The patches look like those caused by the sting of the wasp appear on the skin, itching, excessive pricking sensation, vomiting, fever and burning sensation are the symptoms of Sheetapitta ${ }^{8}$.

Table 1: Nidana of Rakta dushti ${ }^{9}$

\begin{tabular}{|l|l|l|}
\hline S.No & Nidana & \\
\hline 1 & Ahara & $\begin{array}{l}\text { Rasa - Amla Rasa, Lavana Rasa, Katu Rasa Guna - Tikshna Guna Samidhanya Varga - Kullutha, } \\
\text { Masha, Nishpava Mamsa Varga - Jalaja, Anupa, Prashaha,Bilasaya Mamsa Sakha Varga - Mu- } \\
\text { laka Phala Varga - Karamarda Madya Varga - Souviraka, Sukta Gorasa Varga - Amla Dadhi } \\
\text { Taila Varga - Kusumba Taila, Atasi Taila, Sarshapa Taila Viruddha Ahara }\end{array}$ \\
\hline 2 & Vihara & Ati Anila And Ati Atapa Sevana, Diwaswapna \\
\hline 3 & Manasika & Krodha \\
\hline 4 & Anya Nidana & Chardi Vegarodha, Vamana Ayoga, Dushi Visha, Krimi (Rakta, Pureesha), Sarad Rtu. \\
\hline
\end{tabular}

Samprapthi - Due to Rakta dushti, pitta gets accumulated (Upachaya) as rakta is asraya for pitta. Sheeta marutha sparsa increases the Sheeta guna of Kapha and Vata. Thus, the combined action of both Pitta and Sheeta guna results in the manifestation of Sheetapitta.

Table 2: Samprapthi ghataka

Samprapthi ghatakas

Dosha-Pitta pradhana tridoshaja vyadhi.

Vata - Prana, Udana, Vyana, Samana, Apana

Pitta - Pachaka, Ranjaka, Sadaka, Brajaka

Kapha-Avalambaka, Kledaka, Tarpaka

Agni - Jatharagni, Bhootagni, Dhatwagni

Agni dushti-Mandagni

Srotas - Rasa vaha srotas and Rakta vaha srotas



Chikitsa - In Sheetapitta, treatment of Krimi and Dadru followed by Koshta suddhi and then Kushta chikitsa should be done ${ }^{10}$. Various classics explained Sodhana, Samana and Bahirparimarjana chikitsa for Sheetapitta (Table No.3). In the treatment of Sheetapitta all the yogavahi drugs mentioned in other diseases can be used. 
Table 3: Different treatment aspects of Sheetapitta from various classics

Chikitsa

1) Sodhana Chikitsa ${ }^{11}$

a) Purva karma - Abhyanga with Katu taila and Seka with Ushna jala. b) Vamana - Patola, Arista and Vasaka Kashayam.

c) Virechana - Triphala, Guggulu, Krishna. d) Rakta mokshana after snehana with Mahatiktaka ghrita.

2) Samana Chikitsa

Herbal preparations

a) Navakarsika kwatha ${ }^{12}$

Triphala \& madhu ${ }^{13}$

c) Sita,Madhuka,Guda, Ama-

laki, Chitraka ${ }^{14}$ d) Amrithadi kashyam $^{15}$ e) Agnimantha + Goghrita $^{16}$ f) Amruthadi kwatham $^{17}$ g) Haridra khanda ${ }^{18}$ h) Brihat Haridra Khanda ${ }^{19}$ b)

\section{Yashtimadhukadi}

kashya $^{21}$

k)Yavani Ksheerapaka ${ }^{22}$

l) Pippali vardhamana ${ }^{23}$

m) Lasuna Sevana ${ }^{24} n$ )

Chandana yogam ${ }^{25}$ o)

Dhatri khanda ${ }^{26}$ p) Gam-

bhari ksheerapaka ${ }^{27}$
Herbo-mineral preparations

a) Sheetapitta Bhanjana $\operatorname{ras}^{28}$ b) Vishwesara $\operatorname{ras}^{29}$ c) Talakeswar ras ${ }^{30}$ d) Talakadi vati $^{31}$ e) Manikya ras $^{32}$ f)

Arogya vardhini vati ${ }^{33}$

g) Aswakanchuki $\operatorname{ras}^{34}$ h)

Sarvatho bhadra ras ${ }^{35}$

Mineral preparations

a) Suta bhasma prayoga ${ }^{36}$ b)

Pravala pishti ${ }^{37}$

c) Gandhaka rasayana $\left.{ }^{38} d\right)$

Swarna bhasma ${ }^{39}$ e) Malla

sindhura $^{40}$ f) Yashada

bhasma $^{41}$

\section{3) Bahir parimarjana Chikitsa}

a) Lepa with Durva + Nisha ${ }^{42}$ b) Lepa with Saindhava lavana + Kushta + Sarpi + Surasa swarasa ${ }^{43}$ c) Udvartana with Sarshapa + Haridra + Prapunnada + Kushta + Katu taila ${ }^{44}$ d) Abhyanga with Kshara, Saindhava Lavana and Taila ${ }^{45}$ e) Abhyanga with Durvadi tailam (Durva, Sarja, Yashti, Patha, Amrutha, Haridra ${ }^{46}$

\section{DISCUSSION}

Increased Sheeta guna of Kapha and Vata (Sheeta marutha sparsa), when comes in contact with Tikshna and other gunas (increased due to Rakta dushti, Table No 1) of Pitta, Pitta chaya occurs ${ }^{47}$. It was explained in Madhukosa, that pitta which is increased because of its own reasons when comes in contact with cold breeze causes the disease, Sheetapitta ${ }^{48}$. Hence, the $n i$ dana explained by acharyas for Sheetapitta is a Vyanjaka hetu (Trigger factor). This is the probable reason for naming the disease as Sheetapitta. Nidana causes Rakta dushti by the movement of doshas from Koshta to Sakha. As rakta is asraya for pitta, pitta gets aggravated further. Sheeta marutha sparsa increases the Sheeta guna of Kapha and Vata. The combined effect of both Pitta and Sheeta guna results in the acute manifestation of Sheetapitta. Due to repeated exposure to nidana doshas goes on increasing i.e., Vriddhi and Paka of doshas occur, resulting in movement of doshas from Sakha to Koshta. Thus the formation of Ama, which is due to prolonged improper digestion, resulting from nidana, is responsible for Rakta dushti in turn. When doshas move from Sakha to Koshta, if they are not eliminated by proper sodhana, doshas cause Pachaka pitta or Jatharagni, Bhutagni and
Dhatwagni mandya leading to improper uttarottara dhatu poshana. As Ojas is sapta dhatu sara, improper formation of any dhatu shows its effect on the formation of Ojas, leading to Ojo visramsa. Ojas being the adhistana for Bala, decrease in bala takes place. This ultimately causes Dhee, Dhruthi and Smrithi vibramsha (Manas sparsa) and aggravates all the doshas in the body ${ }^{49}$, as a chronic manifestation of Sheetapitta. In both acute and chronic manifestations all the three doshas (pitta dosha pradhana) along with rajo dosha (manasika dosha) is involved. Rajo dosha is responsible for Krodha. Doshas which are already excited due to viruddha ahara etc., under sudden vega of krodha, ushnatwa of body increases, leading to movement of doshas from Koshta to Sakha. Here krodha acts as Vyanjaka hetu (trigger factor). Vata and Kapha are responsible for thoda and kandu respectively. Pitta is responsible for Chardi, Vidaha, Jwara and Varatidastavat (damstra vat) sotha.

\section{CONCLUSION}

Sheetapitta is Pitta pradhana tridoshaja vyadhi caused due to Rakta dushti (Utpadaka hetu) and Sheeta marutha samsparsha (Vyanjaka hetu). In the acute and chronic manifestation of Sheetapitta both 
Sparsnendriya sparsa and Manas sparsa (Dhee, Dhruthi and Smrithi) get deranged (vibramsha), involving Sariraka doshas and Manasika doshas (particularly Rajo guna). Hence the Chikitsa for Sheetapitta can be Sodhana, Rakta suddhi, rational use of Yogavahi dravya and Twachya rasayana.

Flow Chart 1: Samprapthi of Sheetapitta






\section{REFERENCES}

1. Vinaya Pitaka, Hindi translation, Rahul Sanskritayan, The corporate body of the Buddha educational foundation, Pg.No.222

2. Samskrita Sabdardha Koustumbha by Ram Narayana Lal, $2^{\text {nd }}$ edition 1957, Pg.No. 1109

3. Susrutha Samhita, Sutra sthana 21/5, Volume 1, by G.D.Singhal, Chaukhambha Sanskrit Series, Delhi, $2^{\text {nd }}$ edition 2007

4. Anjana Nidana by Dr.S.Suresh Babu, Chowkhambha Sanskrit Series, Varanasi, edition 2004, sloka.206

5. Madhava nidana 50/4 (Madhukosa commentary) Part 2 by Dr P.Himasagara Chandra Murthy, Chowkhambha Sanskrit Series office, Varanasi, edition 2012, sloka

6. Madhava nidana 50/1 Part 2 by Dr P.Himasagara Chandra Murthy, Chowkhambha Sanskrit Series office, Varanasi, edition 2012.

7. Madhava nidana 50/2 Part 2 by Dr P.Himasagara Chandra Murthy, Chowkhambha Sanskrit Series office, Varanasi, edition 2012.

8. Madhava nidana 50/3 Part 2 by Dr P.Himasagara Chandra Murthy, Chowkhambha Sanskrit Series office, Varanasi, edition 2012.

9. Charaka Samhita, Sutra sthana $24 / 5-10$ by Dr.Ram Karan Sharma \& Vaidya Bhagwan Dash, Volume 1, Chowkhambha Sanskrit Series Office, Varanasi, edition 2007

10. Yogaratnakara by Krishna Sharma, Academy of Sanskrit Research, Nirnaya Sagar Yantralaya, edition 1907, Pg.No.376, Sloka.No 14-15.

11. 11\& 21-24. Yogaratnakara by Krishna Sharma, Academy of Sanskrit Research, Nirnaya Sagar Yantralaya, edition 1907, Sheetapitta adhikara Sloka No. 1 - 2, Pg.No 375 .

12. 12 - 20,28,29,30. Bhaishajya Ratnavali chap.55 Volume 3 by Dr.Kanjiv Lochan, Chaukhambha Sanskrit Bhawan, Varanasi, edition 2006.

13. 25. Bharatha Bhaishajya Ratnakara, Vol.2, Pg.No 141 by Sri Nageenadasa Chaganlal Saha, J.J. Offset Prints, edition August 2005.

14. 26. Vrindamadhava or Siddha yoga $52 / 17$ by $\mathrm{Dr}$ Premvati Tewari and Dr Asha Kumari, Chaukhambha Visvabharati, Varanasi, edition 2006.

15. 27. Rajamartanda $8 / 12$ by Dr Nishteswar and Dr R.Vidyanath, Chaukambha Orientalia, Varanasi, 2008.
16. 31,36. Rasa Chandamsu, Uttara tantra Pg.No.358 by Datta Bhaltal Borakar, National Institute of Indian Medical Heritage, New Delhi, edition 2011.

17. 32. Rasendra Chintamani, Pg.No 364, by Prof. Siddhi Nandan Mishra, Chaukhambha Orientalia, Varanasi, edition 2006.

18. 33, 34. Rasa tantra Sara Eva Siddha Prayoga Sangraha, Pg.No.495 \& 319, Krishna Gopal Ayurved Bhavan, Volume 1, edition 2001.

19. 35,37-41. Rasa tantra Sara Eva Siddha Prayoga Sangraha,Pg.No.139, 188, 448, 87, 261 \& 127, Krishna Gopal Ayurved Bhavan, Volume 2, edition 2001.

20. 42. Rasendra Sara Sangraha, Pg.No.880, by Dr.Parimi Suresh and Dr.Vinaya Kumari Dhannapuneni, Chaukhambha Sanskrit Sansthan, Varanasi, edition 2007.

21. 43,44,45. Yogaratnakara by Krishna Sharma, Academy of Sanskrit research, Nirnaya Sagar Yantralaya, edition 1907, Sheetapitta adhikara Sloka No.12,13 \& 3 Pg.No 376.

22. 46. Bharatha Bhaishajya Ratnakara, Vol.3, Pg.No 77 by Sri Nageenadasa Chaganlal Saha, J.J. Offset Prints, edition August 2005.

23. 47. Astanga Hridaya, Sutra sthana $12 / 21$ by $\mathrm{Dr}$ K.R.Srikantha Murthy, Volume 1, Chowkhambha Krishnadas Academy, Varanasi, $5^{\text {th }}$ edition 2007.

24. 48. Madhava nidana 50/1 (Madhukosa commentary) Part 2 by Dr P.Himasagara Chandra Murthy, Chowkhambha Sanskrit Series office, Varanasi, edition 2012, sloka

25. 49. Charaka Samhita, Sharira sthana $1 / 102$ by Dr.Ram Karan Sharma \& Vaidya Bhagwan Dash, Volume 2, Chowkhambha Sanskrit Series Office, Varanasi, edition 2007

\section{Source of Support: Nil Conflict of Interest: None Declared}

How to cite this URL: Mokkapati Archana: Understanding Etiopathogenesis Of Sheetapitta - A Critical Review. International Ayurvedic Medical Journal \{online\} 2021 \{cited July, 2021\} Available from: http://www.iamj.in/posts/images/upload/2998 3002.pdf 